\title{
The role of patch testing in non-immediate drug hypersensitivity reactions
}

\author{
Razvigor Darlenski", Nikolai Tsankov \\ From 3rd WAO International Scientific Conference (WISC) 2014 \\ Rio de Janeiro, Brazil. 6-9 December 2014
}

\section{Background}

Skin is the most commonly affected organ by adverse drug reactions in almost $30 \%$ of all cases. According to the international consensus on drug allergy, drug hypersensitivity reactions (DHRs) constitute $15 \%$ of all adverse drug reactions affecting more than $7 \%$ of the general population.

\section{Methods}

Herein we present case series of various non-immediate DHRs (occurring at any time as from 1 hour after the initial drug administration) amongst which drug-related intertriginous and flexural exanthema (Baboon syndrome), DRESS syndrome, fixed drug eruption and contact dermatitis. In all cases we performed patch testing with standardized and allergens prepared at our laboratory with the suspected drugs. The timing of patch test procedure was in median 6 weeks after the resolution of skin changes.

\section{Results}

Based on the patch test results, we comment on the sensitivity and specificity of patch test in non-immediate DHRs. Different variables influence patch testing in DHRs such as allergen preparation, vehicle, concentration, intake of certain medications and testing healthy controls with the suspected allergens. We emphasize on these and on the demand for control and interpretation of the results. The role of web drug allergen databases in preparation of proper drug concentration and vehicle for patch testing is reviewed.

\section{Conclusions}

This presentation reports the personal experience with in vivo skin patch testing in patients with non-immediate DHRs.

\footnotetext{
Tokuda Hospital, Sofia, Bulgaria
}

C) 2015 Darlenski and Tsankov; licensee BioMed Central Ltd. This is an Open Access article distributed under the terms of the Creative
Cite this article as: Darlenski and Tsankov: The role of patch testing in non-immediate drug hypersensitivity reactions. World Allergy Organization Journal 2015 8(Suppl 1):A2.
Submit your next manuscript to BioMed Central and take full advantage of:

- Convenient online submission

- Thorough peer review

- No space constraints or color figure charges

- Inclusion in PubMed, CAS, Scopus and Google Scholar

- Research which is freely available for redistribution

www.biomedcentral.com/submit
- Immediate publication on acceptance
Published: 8 April 2015

\section{Biomed Central}

